\title{
PEMANFAATAN KULIT SINGKONG SEBAGAI BAHAN BAKU PEMBUATAN NATRIUM KARBOKSIMETIL SELULOSA
}

\author{
Shella Permatasari Santoso, Niko Sanjaya, Aning Ayucitra*, Antaresti \\ Kelompok Keahlian Rekayasa Proses, Jurusan Teknik Kimia, Fakultas Teknik \\ Universitas Katolik Widya Mandala \\ Jalan Kalijudan 37, Surabaya 60114 \\ Email: aayucitra@yahoo.com
}

\begin{abstract}
Abstrak
Kulit singkong merupakan sumber selulosa yang berlimpah dan murah, dengan kadar selulosa $80-85 \%$ dari berat kulit singkong. Tujuan penelitian ini adalah memanfaatkan selulosa dalam kulit singkong sebagai bahan baku pembuatan natrium karboksimetil selulosa (Na-CMC), mempelajari pengaruh natrium hidroksida, natrium kloroasetat serta suhu pada karakteristik Na-CMC seperti perolehan, kemurnian, dan derajat substitusi, serta menentukan kondisi operasi optimum untuk pembuatan Na-CMC berdasarkan kemurnian Na-CMC terbesar. Gugus fungsi Na-CMC ditentukan menggunakan Fourier Transform Infrared Spectra. Mula-mula, kulit singkong dikeringkan dan dihancurkan sehingga berukuran 50 mesh. Kulit singkong diekstraksi dengan $\mathrm{NaOH} 10 \%$ di suhu $35{ }^{\circ} \mathrm{C}$ selama 5 jam, untuk melarutkan lignin. Kulit singkong bebas lignin diekstrak dengan asam asetat $10 \%$ dan natrium klorida dengan pemanasan $750{ }^{\circ} \mathrm{C}$ selama 1 jam untuk melarutkan hemiselulosa sehingga didapatkan selulosa. Alkalisasi dilakukan dengan mereaksikan selulosa dengan $\mathrm{NaOH} 10-40 \%$ dengan pelarut isopropil alkohol pada suhu $30{ }^{\circ} \mathrm{C}$ selama 90 menit, dilanjutkan eterifikasi dengan natrium kloroasetat 1-5 g pada suhu $50-80{ }^{\circ} \mathrm{C}$ selama 6 jam. Berdasarkan hasil penelitian, karakteristik Na-CMC terbaik didapatkan dari alkalisasi selulosa menggunakan $\mathrm{NaOH} 20 \%$ serta eterifikasi menggunakan 3 g natrium kloroasetat pada suhu $70^{\circ} \mathrm{C}$. Perolehan Na-CMC yang didapat adalah sebesar 22\%, kemurnian 96,20\%, derajat substitusi 0,705; termasuk dalam grade kedua menurut SNI 06-3736-1995.
\end{abstract}

Kata kunci: kulit singkong, karboksimetil selulosa, Na-CMC, eterifikasi

\begin{abstract}
THE USE OF CASSAVA PEELS AS RAW MATERIAL FOR SODIUM CARBOXYMETHYL CELLULOSE PRODUCTION. Cassava peels are abundantly available and may be used as an lowcost cellulose source $(80-85 \%$ cellulose per weight cassava peel). the study was to evaluate the effect of the concentration of sodium hydroxide, sodium chloroacetate, and temperature reaction on the sodium carboxymethyl cellulose (sodium-CMC) characteristics i.e. yield, purity, and degree of substitution in sodium-CMC preparation. Sodium-CMC functional group was determined using FTIR spectrophotometer. Cassava peels was dried and grounded to 50 mesh. Lignin was eliminated from cassava peel by extraction of grounded cassava peel with $10 \% \mathrm{NaOH}$ at $35^{\circ} \mathrm{C}$ for $5 \mathrm{~h}$. Cassava peel free lignin was then reextracted using $10 \%$ of acetic acid and sodium chloride at $75{ }^{\circ} \mathrm{C}$ for $1 \mathrm{~h}$, thus cellulose free hemicellulose was obtained. Alkalization at $30{ }^{\circ} \mathrm{C}$ for $90 \mathrm{~min}$ was performed by adding sodium hydroxyde at $10-40 \%$ to cellulose using isopropyl alcohol solvent. Following this, etherification was conducted by adding sodium chloroacetate of $1-5 \mathrm{~g}$ at $50-80{ }^{\circ} \mathrm{C}$ for $6 \mathrm{~h}$. As result, the highest purity of sodium-CMC (96.20\%) was obtained from alkalization using $20 \%$ of sodium hydroxide and etherification using 3 g sodium chloroacetate at $70{ }^{\circ} \mathrm{C}$. Sodium-CMC yield was $22 \%$ and degree of substitution 0.705 .
\end{abstract}

Keywords: cassava peel, carboxymethyl cellulose, sodium-CMC, etherification *penulis korespondensi 


\section{PENDAHULUAN}

Indonesia merupakan salah satu negara penghasil singkong terbesar dalam bidang pertaniannya. Oleh karena itu, limbah kulit singkong sebagai residu pertanian tersedia dalam jumlah yang melimpah (Agrica, 2007). Produksi singkong sebesar 19,5 juta ton dengan area seluas 1,24 juta ha menyebabkan berat kulit singkong dapat mencapai sekitar 3,9 juta ton (Prihandana dkk., 2007). Dalam kulit singkong terkandung selulosa sebesar $80-85 \%$ dari berat kulit singkong (Tabel 1), sehingga memiliki potensi ekonomi. Angka limbah kulit singkong tersebut cukup tinggi dan sangat disayangkan jika kandungan selulosa yang tinggi tersebut tidak dimanfaatkan lebih lanjut.

Tabel 1. Komposisi Kulit Singkong

\begin{tabular}{lc}
\hline Komposisi & Persentase(\%) \\
\hline Abu & 6,3 \\
Air & 9,8 \\
Serat (termasuk selulosa) & 83,9 \\
\hline
\end{tabular}

Sumber: Adegbola dan Asaolu, 1986

Untuk menghasilkan turunan selulosa dengan sifat yang lebih menguntungkan, baik dari sisi ekonomi maupun aplikasinya dalam bidang pangan, perlu dilakukan konversi selulosa misalnya menjadi sodium karboksimetil selulosa (Na-CMC). Na-CMC mampu meningkatkan kualitas produk pangan karena sifatnya sebagai pengikat, penstabil, penahan air, serta pengental (Biswal dan Singh, 2004; Ferdiansah, 2010). Penelitian yang memanfaatkan limbah kulit jeruk dan kulit pisang telah dilakukan oleh Yasar dkk. (2007) dan Adinugraha dkk. (2005) dengan hasil terbaik kemurnian NaCMC sebesar 98,63\% dan DS 0,75 pada kondisi operasi menggunakan $15 \% \mathrm{NaOH}$, pelarut isopropil alkohol, dan suhu eterifikasi $55^{\circ} \mathrm{C}$ untuk kulit pisang.Akan tetapi, penelitian untuk menghasilkan Na-CMC dari kulit singkong masih terbatas dan belum diteliti secara khusus.

Pada penelitian ini, Na-CMC dari kulit singkong diperoleh dengan alkalisasi antara selulosa dengan $\mathrm{NaOH}$ dalam pelarut isopropil alkohol yang dilanjutkan dengan eterifikasi menggunakan sodium kloroasetat (SCA). Tujuan dari penelitian ini adalah memanfaatkan selulosa dalam kulit singkong sebagai bahan baku pembuatan $\mathrm{Na}-\mathrm{CMC}$ dan mempelajari pengaruh sodium hidroksida, sodium kloroasetat serta suhu terhadap karakteristik Na-CMC seperti perolehan, kemurnian, dan derajat substitusi serta menentukan kondisi operasi optimum untuk pembuatan Na-CMC berdasarkan kemurnian Na-CMC terbesar. Gugus fungsional Na-CMC ditentukan menggunakan Fourier Transform Infrared Spectra (FTIR).

\section{METODE}

Selulosa yang terdapat pada kulit singkong dikonversi menjadi sodium karboksimetil selulosa (Na-CMC) melalui proses alkalisasi dan eterifikasi. Penelitian ini terbagi dalam tiga tahap utama, yaitu: (1) tahap persiapan bahan baku, (2) alkalisasi dengan $\mathrm{NaOH}$ dan eterifikasi dengan SCA, (3) tahap penetralan karboksimetil selulosa. Selanjutnya, dilakukan uji kualitatif untuk mengidentifikasi senyawa karboksimetil selulosa (CMC) serta dilakukan penentuan karakteristik Na-CMC yang meliputi perolehan, kemurnian, dan derajat substitusi. Gugus fungsi Na-CMC ditentukan menggunakan FTIR.

\section{Persiapan Selulosa dari Kulit Singkong \\ Kulit singkong dicuci untuk} menghilangkan pengotor, kemudian dijemur di bawah sinar matahari dan dikeringkan dalam oven bersuhu $50{ }^{\circ} \mathrm{C}$ selama 2 jam. Kulit singkong kering dihaluskan dan diayak hingga diperoleh bentuk serbuk kulit singkong berukuran 50 mesh. Serbuk Kulit singkong ditimbang sebanyak $50 \mathrm{~g}$ secara analitis, kemudian ditambahkan $\mathrm{NaOH} \quad 10 \%$ mol sebanyak 1 L untuk menghilangkan lignin dari kulit singkong atau delignifikasi (Togrul and Arslan, 2004; Adinugraha dkk., 2005; Yasar dkk., 2007). Delignifikasi dilakukan selama 5 jam pada suhu $35{ }^{\circ} \mathrm{C}$ dengan menggunakan penangas air. Padatan selulosa dan hemiselulosa dipisahkan dari larutan lignin (black liquor) dengan filtrasi menggunakan kertas Whatmann $110 \mathrm{~mm}$. Padatan bebas lignin kemudian dicuci dengan akuades sebanyak dua kali.

Padatan bebas lignin ditimbang sebanyak $25 \mathrm{~g}$, kemudian ditambahkan 100 $\mathrm{mL}$ akuades, $5 \mathrm{~mL}$ asam asetat $(10 \% \mathrm{v} / \mathrm{v})$, dan $2 \mathrm{~g}$ natrium klorida di dalam gelas piala. Campuran kemudian dipanaskan dengan suhu $75{ }^{\circ} \mathrm{C}$ selama 1 jam sambil diaduk dengan kecepatan $500 \mathrm{rpm}$, kemudian disaring untuk memisahkan padatan selulosa dari hemiselulosa. Pulp hasil penyaringan dibilas dengan $m$ akuades dan etanol masing-masing 
sebanyak $50 \mathrm{~mL}$, lalu disaring kembali. Pulp selulosa kemudian dikeringkan pada suhu 50 ${ }^{\circ} \mathrm{C}$ selama 16 jam (Togrul and Arslan, 2004; Adinugraha dkk., 2005; , Yasar dkk., 2007).

\section{Pembuatan Na-CMC}

Selulosa sebanyak 2 g dialkalisasi dengan menambahkan $100 \mathrm{~mL}$ isopropil alkohol dan $20 \mathrm{~mL} \mathrm{NaOH}(10 \%, 20 \%, 30 \%$, $40 \%$ mol) ke dalam labu leher tiga sambil diaduk selama 90 menit dengan kecepatan $500 \mathrm{rpm}$ pada suhu $30^{\circ} \mathrm{C}$. SCA $(1,2,3,4$, dan 5 g) ditambahkan ke dalam campuran sehingga terjadi eterifikasi, kemudian diaduk dengan kecepatan 500 rpm selama 6 jam sambil dilakukan pemanasan pada 50, 60, 70, dan 80 ${ }^{\circ} \mathrm{C}$. Na-CMC kasar disaring dengan menggunakan corong buchner dan dibilas menggunakan asam asetat $90 \% \quad(\mathrm{v} / \mathrm{v})$ sebanyak $50 \mathrm{~mL}$ untuk menetralkan kelebihan $\mathrm{NaOH}$, dilanjutkan pembilasan dengan metanol 70\% (v/v), kemudian disaring. Padatan Na-CMC kemudian dikeringkan pada suhu $50{ }^{\circ} \mathrm{C}$ sampai didapatkan massa yang konstan (Togrul and Arslan, 2004; Adinugraha dkk., 2005; Yasar dkk., 2007).

Semua sampel Na-CMC dianalisis perolehan, kemurnian, dan derajat substitusinya. Na-CMC dengan kemurnian dan perolehan terbesar dianalisis gugus fungsinya dengan menggunakan FTIR.

\section{Uji Kualitatif dan Karakterisasi Na-CMC}

Keberadaan senyawa Na-CMC dapat ditentukan secara kualitatif ditandai dengan adanya perubahan warna. Adanya kandungan senyawa Na-CMC dalam sampel ditandai dengan munculnya warna merah keunguan pada sampel yang diuji. Uji kualitatif Na-CMC dilakukan dengan standar metode dari FAO (FAO, 2011). Secara kuantitatif, kemurnian serta derajat substitusi Na-CMC ditentukan menggunakan metode standard ASTM D 1439-1994 (ASTM, 1994).

\section{Perolehan Na-CMC}

Na-CMC merupakan senyawa turunan selulosa yang larut dalam air dingin maupun panas. Konversi selulosa menjadi Na-CMC dilakukan dengan alkalisasi menggunakan $\mathrm{NaOH}$ dalam pelarut isopropil alkohol, dilanjutkan eterifikasi menggunakan SCA dengan rumus kimia $\mathrm{ClCH}_{2} \mathrm{COONa}$ dalam keadaan basa. Reaksi yang terjadi adalah sebagai berikut:
$\mathrm{R}_{\text {selulosa }} \mathrm{OH}+\mathrm{NaOH}+\mathrm{ClCH}_{2} \mathrm{COONa}$

$\mathrm{R}_{\text {selulosa }} \mathrm{OCH}_{2} \mathrm{COONa}+\mathrm{NaCl}+\mathrm{H}_{2} \mathrm{O}$

Selain reaksi pembentukan Na-CMC, terjadi juga reaksi antara $\mathrm{NaOH}$ dengan SCA membentuk produk samping berupa sodium glikolat dan sodium klorida berdasarkan reaksi berikut:

$\mathrm{NaOH}+\mathrm{ClCH}_{2} \mathrm{COONa} \rightarrow \mathrm{HO}-\mathrm{CH}_{2} \mathrm{COONa}+\mathrm{NaCl}$

Sodium glikolat dan sodium klorida memiliki kelarutan yang sangat rendah dalam air dingin dibandingkan dengan Na-CMC. Kelarutan sodium glikolat dan sodium klorida dalam air $\left(20^{\circ} \mathrm{C}\right)$ adalah $46,4 \mathrm{~g} / 100 \mathrm{~mL}$ dan $35,89 \mathrm{~g} / 100 \mathrm{~mL}$ (Aldrich, 2006), sedangkan $\mathrm{Na}-\mathrm{CMC}$ memiliki kelarutan yang tinggi dalam air yaitu >100 g/100 mL (Kamel dkk., 2008). Oleh karena itu, penentuan perolehan Na-CMC dilakukan dengan cara melarutkan sampel NaCMC ke dalam air dingin untuk memisahkannya dari by-product dan selulosa yang tidak terkonversi menjadi Na-CMC.

Sampel Na-CMC dilarutkan dalam air dingin $20^{\circ} \mathrm{C}$ dengan rasio sampel dan air 1:20 (b/b), kemudian diaduk selama 10 menit. Padatan dan larutan Na-CMC dipisahkan dengan metode filtrasi. Padatan kemudian dikeringkan pada suhu $70{ }^{\circ} \mathrm{C}$ sampai diperoleh berat konstan. Besarnya perolehan Na-CMC dihitung menggunakan persamaan berikut:

$\%$ Perolehan $=\frac{\text { berat awal sampel }}{\text { berat akhir sampel }} \times 100 \%$

\section{Gugus Fungsional Na-CMC}

Sampel Na-CMC dengan hasil yang paling optimal, yaitu dengan alkalisasi menggunakan $\mathrm{NaOH} 20 \%$ dan eterifikasi menggunakan SCA $3 \mathrm{~g}$ pada suhu $70^{\circ} \mathrm{C}$, dianalisis gugus fungsinya. Sebanyak $3 \mathrm{mg}$ sampel ditumbuk bersama kalium bromida (KBr) sebanyak $800 \mathrm{mg}$. Campuran dipress sehingga menjadi lempeng tipis dengan diameter $\pm 1 \mathrm{~cm}$. Spektrum FTIR direkam pada bilangan gelombang $4000-400 \mathrm{~cm}^{-1}$.

\section{HASIL DAN PEMBAHASAN \\ Optimalisasi Kondisi Reaksi}

Pada penelitian ini dipelajari kondisi reaksi yang optimum untuk pembentukan NaCMC. Mula-mula divariasikan konsentrasi $\mathrm{NaOH}$ yaitu $2 \%, 10 \%, 20 \%, 30 \%$ dan $40 \%$ dengan konsentrasi SCA $3 \mathrm{~g}$ dan suhu $70{ }^{\circ} \mathrm{C}$. Kemurnian Na-CMC tertinggi $(96,2 \%)$ dan 
perolehan terbesar (22\%) diperoleh dari proses dengan konsentrasi $\mathrm{NaOH} \quad 20 \%$. Berdasarkan pustaka, kondisi optimum pembuatan Na-CMC dari kulit pisang didapat pada konsentrasi $\mathrm{NaOH} 20 \%$ dan suhu eterifikasi $70{ }^{\circ} \mathrm{C}$ (Togrul dan Arslan, 2003). Kondisi ini selanjutnya dipergunakan untuk mempelajari pengaruh variasi konsentrasi SCA pada karakteristik Na-CMC. Variasi konsentrasi SCA yang digunakan adalah 1, 2, 3 , 4, dan 5 g dengan konsentrasi $\mathrm{NaOH} 20 \%$ dan suhu $70^{\circ} \mathrm{C}$. Hasil penelitian menunjukkan bahwa konsentrasi SCA yang memberikan kemurnian Na-CMC tertinggi $(96,2 \%)$ diperoleh pada konsentrasi SCA $3 \mathrm{~g}$. Pengaruh variasi temperatur terhadap karakteristik NaCMC dipelajari dengan menggunakan konsentrasi $\mathrm{NaOH}$ dan SCA yang memberikan kemurnian Na-CMC tertinggi yaitu $20 \%$ dan 3 $\mathrm{g}$, secara berurutan. Variasi suhu yang digunakan adalah 50, 60, 70, dan $80{ }^{\circ} \mathrm{C}$. Kemurnian Na-CMC tertinggi didapatkan pada suhu $70^{\circ} \mathrm{C}$.

\section{Bukti Keberadaan Senyawa Na-CMC}

Keberadaan senyawa Na-CMC yang dibuat melalui reaksi alkalisasi-eterifikasi kulit singkong dibuktikan melalui uji kualitatif pembentukan warna berdasarkan metode standar FAO tahun 2011. Larutan Na-CMC yang didapatkan dari penelitian dengan cara melarutkan padatan Na-CMC dalam aquades diletakkan dalam tabung reaksi sebanyak 1 $\mathrm{mL}$. Selanjutnya, diteteskan reagen 1-naftol dan asam sulfat pekat $\left(\mathrm{H}_{2} \mathrm{SO}_{4}\right)$ yang menyebabkan terbentuknya dua lapisan yang memiliki warna yang berbeda. Keberadaan senyawa Na-CMC ini ditandai dengan munculnya warna merah keunguan pada bagian bawah tabung reaksi sedangkan pada lapisan bagian atas jernih (FAO, 2011).

\section{Pengaruh Variasi Konsentrasi $\mathrm{NaOH}$}

Pembentukan Na-CMC dipengaruhi oleh pembentukan alkali-selulosa melalui alkalisasi selulosa dengan NaOH. Dari Gambar 1(a)-(c) dapat dilihat bahwa konsentrasi

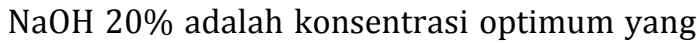
memberikan kemurnian Na-CMC tertinggi $(96,2 \%)$, perolehan terbesar, serta derajat substitusi/DS tertinggi. Setelah mencapai nilai optimum, kemurnian, perolehan, dan DS NaCMC menurun. Dilihat dari kemurniannya, NaCMC turunan dari kulit singkong ini termasuk dalam grade kedua atau teknis berdasarkan SNI 06-3736-1995 (SNI, 1995).

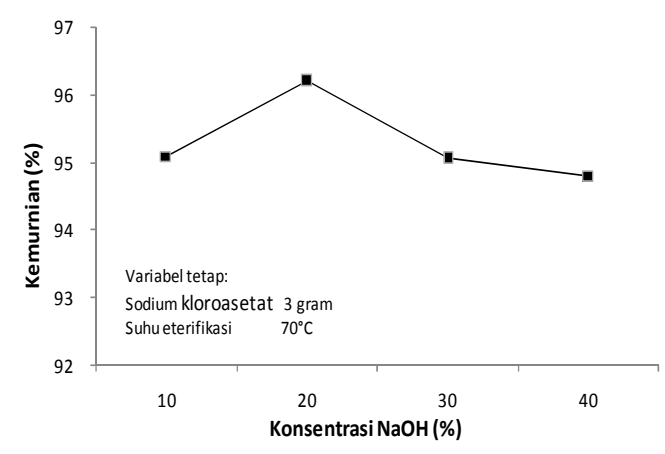

(a)

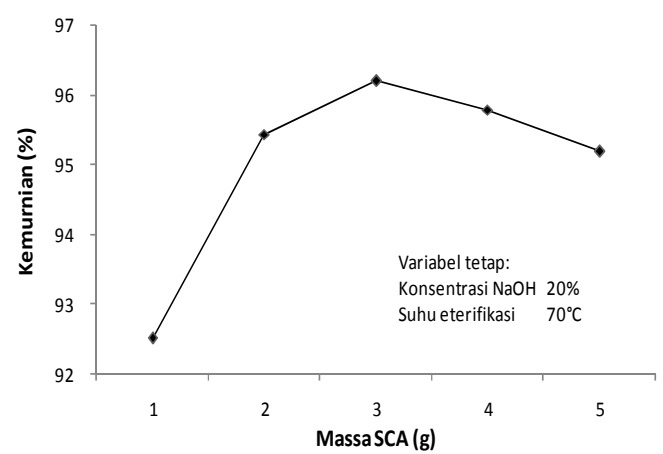

(b)

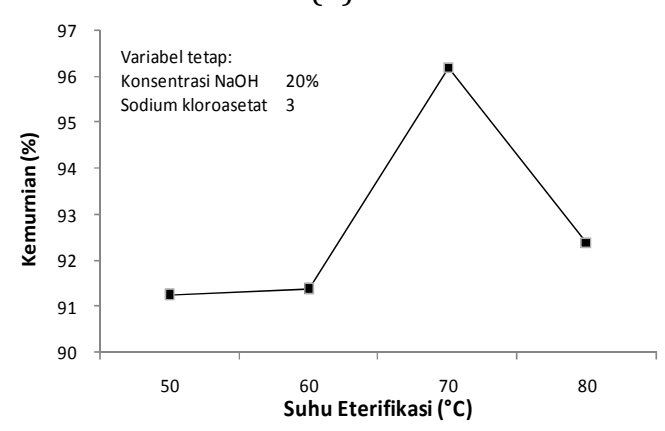

(c)

Gambar 1. Pengaruh konsentrasi $\mathrm{NaOH}$ pada: (a) kemurnian Na-CMC; (b) perolehan Na-CMC; dan (c) DS dari Na-CMC

Perolehan dan DS yang optimum dicapai pada konsentrasi $\mathrm{NaOH} 20 \%$ dengan konsentrasi SCA $3 \mathrm{~g}(0,21 \mathrm{M})$ dan suhu $70{ }^{\circ} \mathrm{C}$, yaitu berturut-turut $22 \%$ dan 0,705 . Pada penelitian ini, didapatkan DS dengan rentang 0,102-0,705 untuk berbagai karakteristik NaCMC yang didapat memiliki nilai yang belum optimum pada saat konsentrasi $\mathrm{NaOH}$ yang ditambahkan rendah $(2 \%$ dan $10 \%)$. Ini disebabkan konsentrasi $\mathrm{NaOH}$ yang terlalu rendah atau terbatas untuk mengkonversi selulosa menjadi alkaliselulosa. Alkaliselulosa bereaksi dengan SCA menjadi Na-CMC. Berdasarkan pustaka FAO(2011), rentang DS untuk Na-CMC hasil dari reaksi alkalisasi oleh 
$\mathrm{NaOH}$ dilanjutkan reaksi karboksimetilasi oleh SCA adalah antara 0,20-1,50. Apabila DS dari Na-CMC kurang dari 0,20 maka kelarutan Na-CMC sangat kecil, sedangkan apabila DS di atas 0,20 akan membuat Na-CMC larut dan hidroafinitas dari Na-CMC akan meningkat (Waring dan Parsons, 2001; Adinugraha dkk., 2005,).

Penurunan kemurnian, perolehan, dan DS dari Na-CMC setelah mencapai kondisi optimum (konsentrasi $\mathrm{NaOH} 20 \%$ ), yaitu pada saat konsentrasi $\mathrm{NaOH}$ tinggi (30\% dan 40\%), disebabkan oleh Na-CMC yang terbentuk akan terdegradasi oleh $\mathrm{NaOH}$ yang berlebihan. Di samping itu, kelebihan $\mathrm{NaOH}$ juga akan bereaksi dengan SCA membentuk sodium glikolat dan sodium klorida sebagai produk samping yang membuat pembentukan NaCMC berkurang (Togrul dan Arslan, 2003; Pushpalamar dkk., 2006,).

\section{Pengaruh Konsentrasi SCA}

Pengaruh konsentrasi SCA dipelajari dengan memvariasikan konsentrasi SCA, yaitu $1,2,3,4$ dan 5 g. Dari Gambar 2(a) dan 2(b), terlihat bahwa kemurnian dan perolehan dari Na-CMC terus meningkat seiring dengan bertambahnya konsentrasi SCA dan mencapai titik optimum pada konsentrasi SCA 3 g $(0,21$ M) dengan kemurnian $96,20 \%$ dan perolehan 21,94\%; setelah itu kemurnian dan perolehan dari Na-CMC menunjukan penurunan. Begitu pula untuk DS, pada Gambar 2(c), dapat dilihat DS optimum sebesar 0,705 didapat pada saat konsentrasi SCA 3 g.

Pada saat massa SCA yang ditambahkan rendah (1 dan $2 \mathrm{~g}$ ), pembentukan Na-CMC belum optimum disebabkan oleh terbatasnya konsentrasi SCA yang mengkonversi gugus hidroksil selulosa menjadi Na-CMC. Pada massa SCA tinggi, yaitu 4 g dan 5 g, terjadi kelebihan reaktan SCA. Kelebihan SCA ini akan bereaksi dengan $\mathrm{NaOH}$ membentuk byproduct sodium glikolat seperti pada reaksi (2). Pada saat konsentrasi $\mathrm{NaOH}$ dan SCA yang tinggi digunakan dalam reaksi pembentukan Na-CMC, reaksi samping (pembentukan sodium glikolat) menjadi lebih dominan dibandingkan reaksi utama yaitu pembentukan Na-CMC, dan menyebabkan penurunan DS, kemurnian Na-CMC, serta menurunkan efisiensi reaksi yang berakibat pada penurunan perolehan Na-CMC (Barai dkk., 1997; Adinugraha dkk., 2005,).

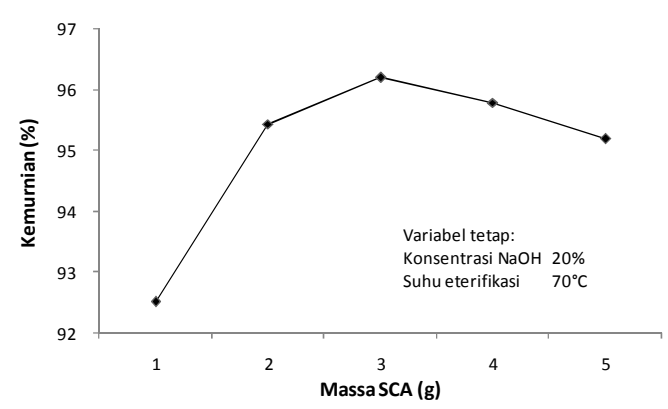

(a)

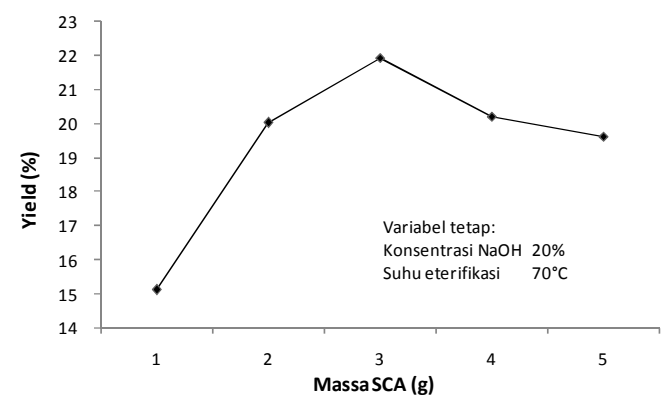

(b)

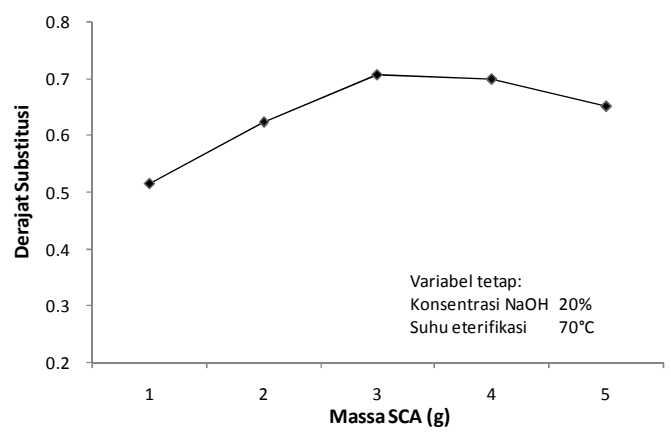

(c)

Gambar 2. Pengaruh konsentrasi SCA pada (a) kemurnian $\mathrm{Na}-\mathrm{CMC}$; (b) perolehan $\mathrm{Na-}$ CMC; dan (c) DS dari Na-CMC

\section{Pengaruh SuhuEterifikasi}

Karakteristik Na-CMC terbaik didapatkan pada kondisi operasi dengan konsentrasi $\mathrm{NaOH}$ saat reaksi alkalisasi adalah $20 \%$ dan massa SCA yang digunakan adalah 3 g $(0,21 \mathrm{M})$ dan temperatur $70{ }^{\circ} \mathrm{C}$. Gambar 3 menunjukkan pengaruh temperatur reaksi eterifikasi terhadap kemurnian, perolehan, dan DS dari Na-CMC.

Seperti yang terlihat pada Gambar 3(a), kemurnian Na-CMC mengalami peningkatan seiring dengan kenaikan temperatur eterifikasi dan mencapai nilai optimum yaitu sebesar 96,2\%, pada saat eterifikasi dengan temperatur $70{ }^{\circ} \mathrm{C}$, kemudian mengalami penurunan. Pada Gambar 3(b), dapat dilihat bahwa perolehan Na-CMC mengalami peningkatan dan mencapai nilai optimum 
$(21,94 \%)$ saat eterifikasi dengan temperatur $70{ }^{\circ} \mathrm{C}$. DS dari Na-CMC semakin tinggi apabila temperatur eterifikasi semakin tinggi, akan tetapi mengalami penurunan apabila temperatur terlalu tinggi. Pada Gambar 3(c), DS mencapai nilai optimum sebesar 0,705 pada saat temperatur $70{ }^{\circ} \mathrm{C}$ kemudian menurun pada saat temperatur $80^{\circ} \mathrm{C}$.

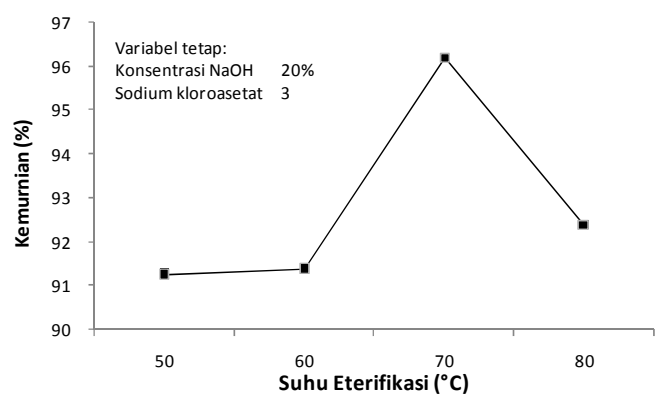

(a)

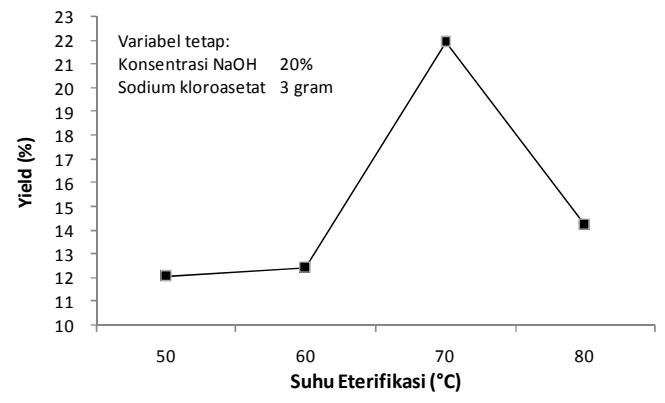

(b)

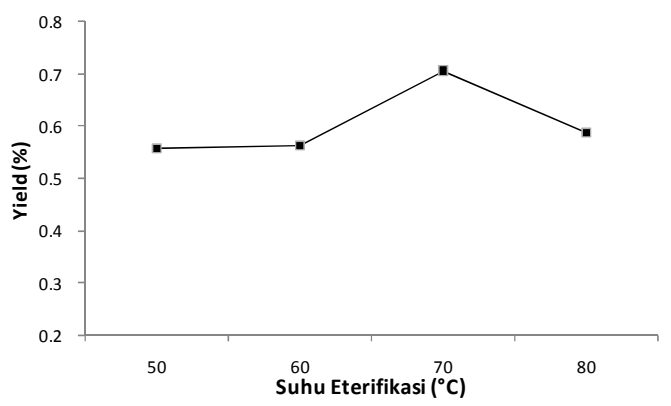

(c)

Gambar 3.Pengaruh suhu eterifikasi pada: (a) kemurnian Na-CMC; (b) perolehan NaCMC; dan (c) DS dari Na-CMC

Penurunan yang terjadi pada nilai karakteristik dari Na-CMC kemungkinan disebabkan oleh degradasi selulosa. Pada saat temperatur tinggi, yaitu $80{ }^{\circ} \mathrm{C}$, alkaliselulosa mengalami degradasi. Degradasi ini mengakibatkan gugus hidroksil pada alkaliselulosa, terutama pada C2 dan C3, akan tereliminasi. Hal ini mengakibatkan berkurangnya gugus hidroksil yang dapat terkonversi menjadi gugus karboksimetil sehingga reaksi pembentukan Na-CMC pun berkurang. Degradasi selulosa mengalami peningkatan seiring dengan kenaikan suhu.

Temperatur optimum reaksi eterifikasi untuk pembentukan Na-CMC adalah $70{ }^{\circ} \mathrm{C}$. Ini disebabkan oleh gugus hidroksil pada rantai karbon C2 dan C3 terbuka dan terkonversi menjadi gugus karboksimetil. Untuk reaksi pada temperatur rendah, yaitu 50 dan $60^{\circ} \mathrm{C}$, ikatan gugus hidroksil pada alkaliselulosa belum terbuka optimal sehingga hanya sedikit dari gugus hidroksil yang terkonversi menjadi gugus karboksimetil atau Na-CMC (Scheir dkk., 2001; Pushpalamar dkk., 2006).

\section{Analisis Gugus Fungsional Na-CMC}

Analisis Spektrum FTIR pada Na-CMC dari kulit singkong dilakukan untuk Na-CMC dengan karakteristik yang paling optimal yaitu Na-CMC dengan kemurnian 96,20\%, perolehan $22 \%$, serta DS 0,705 pada kondisi reaksi menggunakan larutan $\mathrm{NaOH} 20 \%, 3$ g SCA, dan suhu eterifikasi $70{ }^{\circ} \mathrm{C}$. Senyawa karboksimetil dapat diidentifikasi pada panjang gelombang $1601,1 \mathrm{~cm}^{-1}$ dan 1428,3 $\mathrm{cm}^{-1}$ seperti yang terlihat pada Gambar 4 . Berdasarkan pustaka, gugus karboksil diidentifikasi pada panjang gelombang dengan kisaran 1600-1640 $\mathrm{cm}^{-1}$ dan 1400$1450 \mathrm{~cm}^{-1}$ (Pecsok dkk., 1976; Adinugraha dkk., 2005). Absorpsi paling besar pada $1601,1 \mathrm{~cm}^{-1}$, yang menunjukkan keberadaangugus karboksil -COOH. Pita absorpsi pada 1428,3 $\mathrm{cm}^{-1}$, menunjukkan vibrasi menggunting (scissoring) dari gugus $\mathrm{CH}_{2}$. Akan tetapi, intensitas pita absorpsi pada panjang gelombang tersebut relatif lemah. Absorpsi yang cukup besar lainnya terjadi pada pita absorpsi pada panjang gelombang $3761,1 \mathrm{~cm}^{-1}$ dan 1212,9 $\mathrm{cm}^{-1}$ (Gambar 4), menunjukkan adanya gugus $-\mathrm{OH}$ dan $\mathrm{C}-\mathrm{O}$, secara berurutan, sebagai pengotor (Pecsok dkk., 1976; Adinugraha dkk., 2005; Pushpalamar dkk., 2006). 


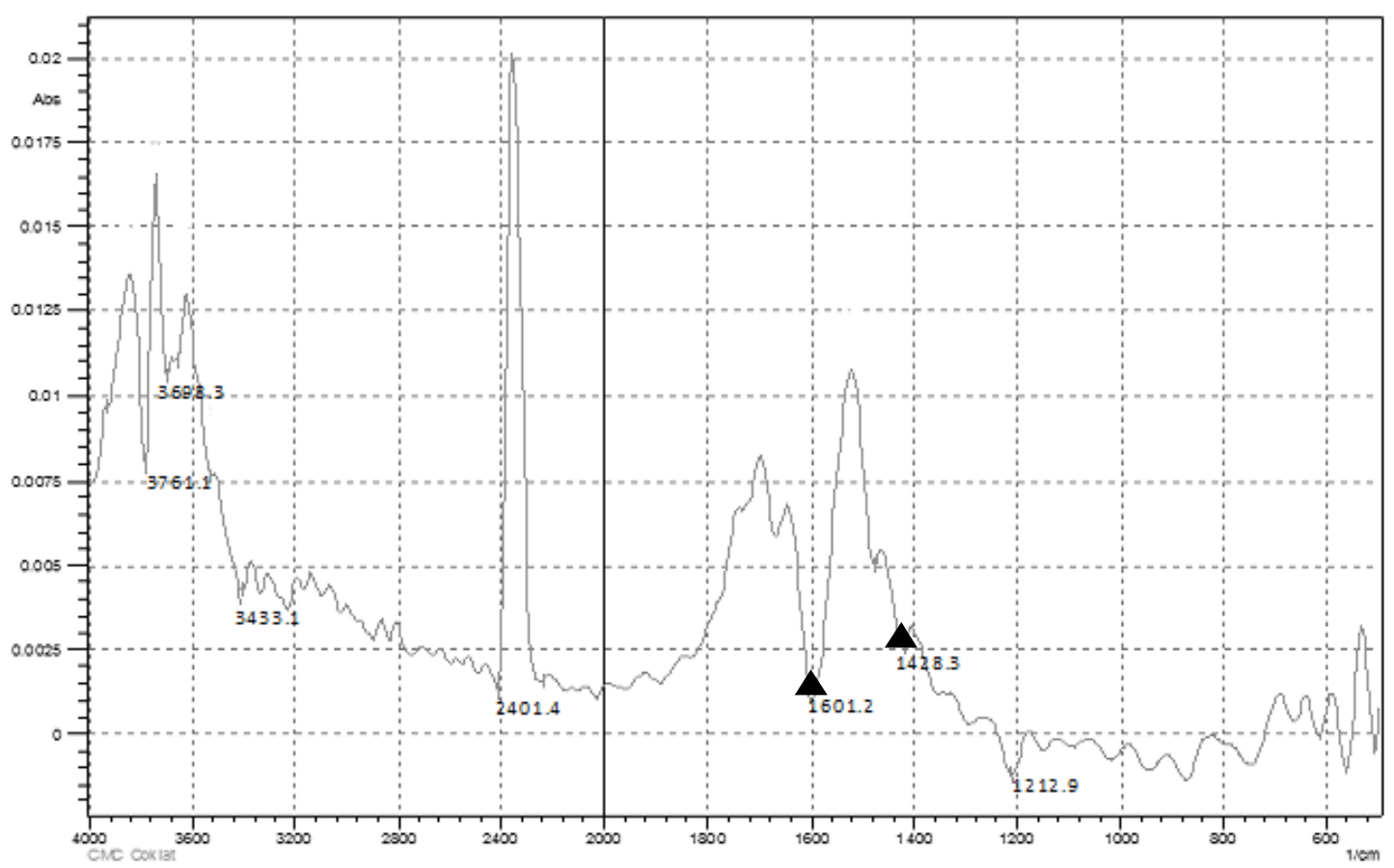

\section{Gambar 4. Spektrum Imparsial dari Na-CMC turunan kulit singkong (simbol $\Delta$ menandakan gugus karboksil)}

\section{KESIMPULAN}

Na-CMC dapat diproduksi dari reaksi karboksimetilasi selulosa yang diperoleh dari kulit singkong. Karakteristik Na-CMC terbaik didapatkan pada saat reaksi alkalisasi oleh $\mathrm{NaOH} 20 \%$ dengan pelarut isopropil alkohol, dilanjutkan eterifikasi oleh SCA $3 \mathrm{~g}$ pada temperatur $70{ }^{\circ} \mathrm{C}$. Karakteristik yang didapat berupa kemurnian Na-CMC sebesar 96,20\%, perolehan sebesar 21,94\%, serta DS 0,705 . Na-CMC yang terbentuk dari kulit singkong ini berupa serbuk dan termasuk dalam grade kedua atau teknis dilihat dari kemunian $\mathrm{Na}-$ CMC berdasarkan SNI 06-3736-1995 (SNI, 1995).

\section{DAFTAR PUSTAKA}

Adinugraha, M. P.; Marseno, D. W.; Haryadi., Synthesis and characterization of sodium carboxymethylcellulose from cavendish banana pseudo stem (Musa cavendishii LAMBERT), Carbohydrate Polymers, 2005, 62(2), 164-169.

Adegbola, A. A.; Asaolu, O., Preparation of Cassava Peels for Use in Small Ruminant Production in Western Nigeria. In: T.R. Preston and M. Y. Nuwanyakapa (eds), Towards optimal feeding of agricultural by-products to livestock in Africa Proceedings of a workshop at University of Alexandria, Egypt, October 1985, ILCA, Addis Ababa, Ethiopia, 1986, hlm. 109-115.

AGRICA, Bensin Singkong, Lembaga Pers Mahasiswa AGRICA Fakultas Universitas Jenderal Soedirman: Purwokerto, 2007.

Sigma-Aldrich, Sodium Hydroxyacetate; MSDS No. CDS000626; Sigma-Aldrich: St. Louis, MO, USA, 2006.

ASTM Standard D-1439-94, Sodium Carboxymethylcellulose, ASTM, West Conshohocken, PA, USA, 1994.

Barai, B. K.; Singhal, R. S.; Kulkarni, P. R., Optimization of a process for preparing carboxymethyl cellulose from water hyacinth (Eichornia crassipes), Carbohydrate Polymers, 1997, 32(3-4), 229-231.

Biswal, D. R.; Singh, R. P., Characterisation of carboxymethyl cellulose and polyacrylamide graft copolymer, Carbohidrate Polymers, 2004, 57(4), 379-387.

FAO, Compendium of food additive specifications, Food and Agriculture 
Organization of the United Nations $74^{\text {th }}$ Meeting, 2011, hlm. 115-119.

Ferdiansah, M. K., Pengelolaan Limbah Buangan Kulit Singkong sebagai Upaya Mendukung Produksi CMC Ramah Lingkungan, 2010, http://www.mediaindonesia.com /webtorial/klh/?ar_id=NzQ2MQ==. (akses Mei 2011)

Kamel, S.; Ali, N.; Jahangir, K.; Shah, S. M.; ElGendy, A. A., Pharmaceutical significance of cellulose: a review, eXPRESS Polymer Letters, 2008, 2(11), 758-778.

Pecsok, R. L.; Shields, L. D.; Cairns, T.; McWilliam, I. G., Modern Method of Chemical Analysis; Wiley and Sons: New York, 1976.

Prihandana, R.; Noerwijan, K.; Adinurani, P. G.; Setyaningsih, D.; Setiadi, S.; Hendroko, R., Bioetanol Ubi Kayu Bahan Bakar Masa Depan, Agromedia: Jakarta, 2007.

Pushpalamar, V.; Langford, S. J.; Ahmad, M.; Lim, Y. Y., Optimization of reaction conditions for preparing carboxymethyl cellulose from sago waste, Carbohydrate Polymers, 2006, 64(2), 312-318.
Scheir, J.; Camino, G.; Tumiatti, W., Overview of water evolution during the thermal degradation of cellulose, European Polymer Journal, 2001, 37(5), 933-942.

Standar Nasional Indonesia, Natrium Karboksi Metil Selulosa Teknis, Dewan Standardisasi Nasional Indonesia: Jakarta, 1995.

Toğrul, H.; Arslan, N., Production of carboxymethyl cellulose from sugar beet pulp cellulose and rheological behavior of carboxymethyl cellulose, Carbohydrate Polymers, 2003, 54(1), 73-82.

Toğrul, H.; Arslan, N., Carboxymethyl cellulose from sugar beet pulp cellulose as a hydrophilic polymer in coating of mandarin, Journal of Food Engineering, 2004, 62(3), 271279.

Waring, M. J.; Parsons, D., Physico-chemical characterization of carboxymethylated spun cellulose fibres, Biomaterials, 2001, 22(9), 903-912.

Yasar, F.; Toğrul, H.; Arslan, N., Flow properties of cellulose and carboxymethyl cellulose from orange peel, Journal of Food Engineering, 2007, 81(1), 187-199. 